\title{
CULTURE EDUCATION-BASED MODEL FOR THE MODERN ORGANISATION
}

\author{
LUDMIŁA WALASZCZYK \\ Sieć Badawcza Łukasiewicz - Instytut Technologii Eksploatacji \\ (Łukasiewicz Research Network - Institute for Sustainable Technologies) \\ Pułaskiego 6/10; 26-600 Radom \\ E-mail address: ludmila.walaszczyk@itee.lukasiewicz.gov.pl \\ ORCID: http://orcid.org/0000-0001-8022-9419
}

\begin{abstract}
Aim. The aim of the research is to support the organisation's management through raising awareness on cultural diversity in the multicultural environment, and presenting a complex model covering the cultural issues in the multicultural organisation.

Methods. The model has been developed based on the research carried out between 2018 and 2021 in the Cultural risk in the organisation in the globalisation era-competences vs. Reality project. The author used literature review and a survey questionnaire as research methods. To develop the model for staff management at a multicultural organisation, a survey questionnaire directed to 154 staff members of multicultural organisations in five countries (Poland, Italy, Latvia, Cyprus, and the UK) was used.

Results. As a result of the analysis, the following key areas have been identified: cross-cultural awareness, understanding different cultures, stereotypes, communication, teamwork, leadership and hierarchy, learning styles, and qualities in the workplace. The improvement of the staff in the aforementioned areas makes them more aware of the cultural diversity in organisations and of different cultural risks that may occur.

Conclusions. There is a strong need for a continued consideration and improvement of the awareness regarding cultural diversity, as it is an element of modern and changing economy which may influence the continuity of every organisation.

Cognitive value. Key topics related to competences for mitigating cultural risks were identified. They were used as elements of the complex model which can be used at a multicultural organisation in the process of training the staff in the area of cultural diversity.
\end{abstract}

Key words: multiculturality in organisation, enterprise management, e-learning

\section{INTRODUCTION}

Towadays, in times of globalisation and open markets, organisations face 1 a number of risks (i.e.: market, financial, cultural, legal, ecological, or political) that might impede their operation. However, given the multicultural 
nature of modern societies, the cultural risk seems to be dominant, as representatives of different cultures neither share the same understanding of nor adopt the same work attitudes.

Nowadays, one of the biggest problems of the EU Member States, as well as of many other countries, seems to concern the refugee and migration crisis - the journey of people from the war-torn Middle East and, to a lesser extent, from Africa, to Europe (Burke, 2019). The number of first-time asylum applicants has dropped from the peak of 1.3 million in 2015 , to 580,000 in 2018, however the forecasts predict a further increase. It could seem that in the times of insufficient labour force, it might be a good solution to employ migrants, but unfortunately the integration of the people with a foreign background depends not only on their willingness to integrate, but also on the willingness of the native populations to accept them, particularly where they end up competing for welfare resources and public services insufficient for greater demand.

Therefore, in order to minimise cultural risks, the enterprise must be interculturally competent and it must have a dedicated strategy aimed at managing a multicultural team (Brünnemann, 2013; Hammer, 2009; Jackson, 2015). Ideally, the whole enterprise should become interculturally competent. Employees must be aware that they can work effectively with people from different cultures.

The article aims at raising awareness of cultural diversity in the organisations and presenting the complex model for culture-based education. The model is an outcome of the research carried out in the Cultural risk in the organisation in the globalisation era - competences vs. reality ERASMUS+ project in five partner countries - Poland, Latvia, Italy, Cyprus, and the United Kingdom.

\section{METHODOLOGY}

The research methodology included three steps:

- Step 1: The literature review on national levels in Poland, Latvia, Italy, Cyprus, and the United Kingdom. The research concerned the deep review of the available literature on the most frequent cultural risks in multicultural organisations.

- Step 2: The survey questionnaire with the representatives of multicultural organisations and individuals interested in the topic of cultural risks in the abovementioned five countries.

- Step 3: The development of the culture education-based model the implementation of which is to be recommended in multicultural organisations to improve employee performance and communication. 


\section{IDENTIFICATION OF THE ELEMENTS OF THE CULTURE EDUCATION-BASED MODEL}

The literature analysis concerned the five countries, so the results have given a broad overview on the cultural risks often occurring in the multicultural organisations.

For Poland, joining the European Union meant opening to new markets and attracting many foreign investors and workforce as well as establishing international cooperation with different entities and organisations from abroad. On the other hand, Poland is a country with a remarkably high bureaucracy rate linking with incompetency and complicated procedures retained from the former system. Polish construction and production industries have been attracting a lot of workers from Eastern Europe, mainly Ukraine (Czainska, 2017), but other sectors (e.g.: IT) are struggling to find qualified workforce, both from Poland and abroad.

As a part of the studies carried out in Poland, the following risks were identified: prejudices and stereotypes; different styles of work (teamwork vs. individual work preferences) (Adamczyk, 2017); communication (Dębczyńska, 2017); modern work methods, such as brainstorming, which may not be stimulating for high-context culture representatives who do not work in the same way as low-context culture representatives. The adopted team integration methods may not work for everyone due to their different ethnic and religious backgrounds (e.g.: in Poland, employers often organise employee Christmas parties or other religious or bank holiday-based events - some foreigners do not celebrate such holidays or may even not tolerate their form) (Kostrzyńska, 2018).

From the UK-based research it follows that those universities, enterprises, and other kinds of organisations are often culturally diverse. Expectations of students, and employees are quite different. Many differences have been identified in the following aspects: balance between individual and group work based on the country's culture favouring individualism vs. collectivism, language barriers (concerning the use of idioms that do not always carry the same meaning for everyone), low or high-power distance cultures (people from a low-power distance culture would be more comfortable debating with others), gender perception (different treatment of genders in different cultures), building trust, intergenerational perspectives (younger employees may be considered immature or their work ethics may be questioned by senior employees).

In the UK, the following key factors have also been identified in the literature e.g.: prejudice and bias (whether unconscious or not) still existing in the workplace, and associated with discrimination (Jones, Peddie, Gilrane, King, \& Gray, 2016; Triana, Jaysinghe, \& Pieper, 2015); inequality - from the lack of women in leadership positions to the perception of applicants with disabilities (McLaughlin, Bell, \& Stringer, 2004); access to jobs - multiple pieces of evidence highlight the issue of bias in recruitment, from job advert wording to call-back rates (Quillian, Pager, Hexel, \& Midtboen, 2017); stigma influencing 
an individual's experience at work, with research shining a light on the barriers faced by those with disabilities.

According to the studies performed in Italy, cultural risks in organisations are also related to the following four identified areas: communication, team building, time, and schedules.

Smooth and effective communication is vital for company's performance. Yet it often proves the most difficult, even impossible, as people from different cultural backgrounds follow different communication protocols and develop different rapport with their supervisors or other team members. Moreover, language barrier does also impede communication and is a problem that many multi-cultural organisations face and struggle with.

People from certain cultures are individualistic and prefer to work alone. Other cultures value cooperation within or among other teams. Team-building issue can become more problematic when teams are comprised of people from a mix of these cultural characteristics. Effective cross-cultural team building is essential to benefit from the potential advantages of cultural diversity in the workplace (Heinz, 2014).

Another aspect that can cause cultural misunderstanding is time. People from different cultures vary in terms of their perspectives of time, e.g., as regards work-life or work-social interactions balance. Other differences include the perception of time, which can threaten deadlines and make everyone's work difficult. Perceptions of time underline the importance of cultural diversity in the workplace and its impact on everyday work (Bussotti, 2017). The aspect of time is strongly related to schedules, which means that task completion is highly dependent on bank or religious holidays (Allievi, 2010).

Studies carried out in Cyprus identified the following risks: isolation, religion, and communication. Isolation may be caused by underlying prejudices, discomfort or unfamiliarity with other ethnic groups, or displeasure with changing policies and procedures. Isolation can also include self-isolation and non-participation i.e., by choice (e.g.: in events held by the organisation) due to cultural differences (Jain \& Pareek, 2019). Religion, for instance, orients cultural differences. Communication as a cultural risk in Cyprus includes the following aspects:

- misunderstandings between employees due to culture-related tactile interaction and gestures (e.g.: handshake, kiss on the cheek or patting on the shoulder);

- different understanding and, as a result, expectations of body language signs or signals;

- avoidance - dislike of body contact (e.g.: in Mediterranean cultures patting on the shoulder is something normal while in other cultures this gesture may be misunderstood or even unwelcome).

Communication in a non-native language may become a risk. Some people are afraid to say "I did not understand that," so the company may be under the wrong impression that something was comprehensible, but it was not understood (Hussain, 2018). 
Finally, in Latvia multiculturalism and associated risks are deemed of great importance. There are various reports and publications that indicate the following risks: different attitudes to conflicts as well as various communication styles; differences in the style of communication can be found even within one culture and they may depend on an individual's personality, social origin, education, etc. (Rožukalne, Kruks, Skulte, Lūse, \& Stakle, 2017). Some people tend to resolve conflicts openly, while others avoid them as much as possible, as they fear that by getting involved in a conflict, they would lose face (Hanovs, 2016). Moreover, it is possible to observe different attitude to fulfilment of tasks: different ways of moving towards the fulfilment of the planned task may be related to practical reasons, such as the availability of resources and motivation and the different understanding of the tactics necessary to achieve an objective, to establishing a good personal relationship before considering any business matters (Brands-Kehre, 2014); different attitude to openness: attitude to openness concerns the expression of emotions and opinions in different situations and contexts. A display of emotions may be viewed as a manifestation of bad manners and weakness. Different perception of and the attitude to time and place has also been observed; different attitude to time is one of the most distinct cultural peculiarities. Traditionally, Western countries perceive time as quantitative, measurable and they look at it from the linear perspective. Time perception is thus based on logic and mathematical arguments. Time is a value, as it has been well said that "time is money," and its most effective use should be ensured. However, the attitude of other cultures to time may vary (Rožukalne et al., 2017).

\section{CULTURAL PROBLEMS IN PRACTICE}

To verify the literature findings in practice, the project partners interviewed representatives of multicultural organisations in their countries using a questionnaire designed for the study. ${ }^{1}$ The research sample included:

- managerial staff from multicultural organisations;

- junior staff from multicultural organisations;

- other individuals who in the past had contact with multicultural organisations, and who faced the risks stemming from cultural diversity.

In total, 154 questionnaires were collected: Cyprus (34), Italy (33), Latvia (30), Poland (30), and the UK (27). The majority of all respondents were the representatives of junior staff $(49 \%), 31 \%$ of all interviewees represented senior or middle management, and $20 \%$ were individuals interested in the topic of cultural risk. Out of all the respondents, $79 \%$ come from a multicultural organisation, $13 \%$ have worked at such an organisation before, and $8 \%$ have never worked at a multi-cultural organisation. In terms of the type of the organisa-

1 The author performed the questionnaire research in Poland. In other countries, the partners performed the survey questionnaires. In this article the author presents the overall results from the research carried out across those five countries. 
tion represented, $54 \%$ of interviewees came from private enterprises, $20 \%$ from NGOs, 9\% from universities or colleges, $6 \%$ from a government organisation, $2 \%$ from a municipal organisation, and $9 \%$ from a different organisation type. The survey was held between January and February 2019.

The questionnaire included eight (8) modules strongly related to the issue of the management of and functioning in a multicultural environment. All competences were evaluated on the scale from 1 to 4 , where " 4 " refers to skills and competences that are required, "3" to skills and competences that are important, " 2 " to skills and competences that are welcome but not vital, and " 1 " to skills and competences that are not needed. Where no decision could be easily made, interviewees could also give the answer "hard to say."

\section{RESULTS}

The results achieved by the project partners are presented in Table 1 included in Appendix. The analysis of the cultural aspects in selected multicultural organisations allows for the conclusion that the majority of the above-listed elements are perceived as crucial (ranked above 3.0). The highest score is related to M2 module and the element: "to understand why people from different cultures can behave differently." Such responses can show that the respondents relate the competences to practical situations that can be encountered in everyday life. What is more, based on the results of M2, it can be noticed that for the interviewees, it is most important to understand the behaviour of people from different cultural backgrounds and the role of tolerance to improve their work in an organisation. That is why also the competence "to understand the role of tolerance between people from different cultures" scored remarkably high (3.63 in Italy). The understanding of tolerance seems to be crucial for good cooperation and life in diverse cultural environments. What can be noticed is that these competences score the highest in the countries where the cultural diversity is observed in everyday practice such as Cyprus and Italy.

Understanding and tolerance are linked with solving problems in the organisation (M5). It comes from the fact that cultural diversity always brings some problems, conscious or unconscious, but finally coping with them is considered a success. Therefore, this aspect is highly scored in all countries that took part in the research.

The lowest scores are related to the elements linked with the definitions and theoretical aspects of the topic. It can stem from the fact that employees do not want to learn the theory but only engage in practice. Therefore, the elements such as "getting familiar with interesting models of culture, i.e.: Iceberg Model of Culture, Hofstede's Cultural Dimensions Theory, Milton Bennett's Cultural Sensitivity Model" received the lowest score (M1). The theory is important if somebody wants to deepen their understanding of a given problem, but it is not indispensable in everyday practice. The same is observed with the definitions of the terms "adaptation" (M5), "cultural stereotypes" (M4) or "inter- 
cultural learning" (M7). The respondents are particularly interested in these topics, but they do not want to learn the definitions which are associated with formal school education.

As for the overall modules (without separating individual competences), it has been noticed that, M6 and M8 - Leadership and Hierarchy and Qualities in the Working Place, are assessed as the least important. It can come from the fact that the respondents belonged to two target groups: managerial staff and the junior staff. M6 and M8 modules are ranked low by the junior staff, because in fact these modules are not directly dedicated to them. They do not pay attention to leadership, or hierarchy. However, there was a decision to include these modules in the model as it is open so if needed, the competences can be added or rejected. As for M8, these competences are a little bit fuzzy (concerning different aspects), and sometimes the respondents had problems with linking them to a specified environment. That is why they often rank these competences low. However, for example, in Cyprus, the most valuable competence was "to identify and analyse other different factors as e.g.: punctuality, precision, and efficiency, which can ensure good work," which belongs to M8.

\section{CULTURE EDUCATION-BASED MODEL}

As a result of the research and analyses carried out, the author identified essential elements for the culture education-based model which could be implemented in the multicultural organisations. In order to build the model, the objective of the culture education-based model for multicultural organisations has been defined. The main objective of the model is to propose a tool aimed at supporting effective management in the multicultural organisation. The application of the model in practice will contribute, among others, to effective management of the organisation; employment and management of the staff from different cultural backgrounds - domestic and foreign employees alike; and the increase in the competitiveness of the enterprise due to the establishment of better employee-employee and employee-employer relations.

In the next step the author proposes the assumptions for the model. To build the model, the author has identified the target group which mainly includes the management board/the owners of the multicultural organisations. The developed model gives several benefits to this group, especially: supporting the decision-making process in multicultural organisations; improving the effectiveness of multicultural organisations' operations; and improving the understanding of cultural diversity in the workplace by the staff and the teamwork skills as a result of the application of the model in the organisation.

The model is open, which makes it possible to include additional elements deemed significant in the process of its practical implementation. Therefore, the necessary changes will be introduced after the practical implementation of the model in multicultural organisations. 
In the last phase, the structure of the model (see Figure 1) has been developed and the author presented the model in descriptive and algorithmic forms.

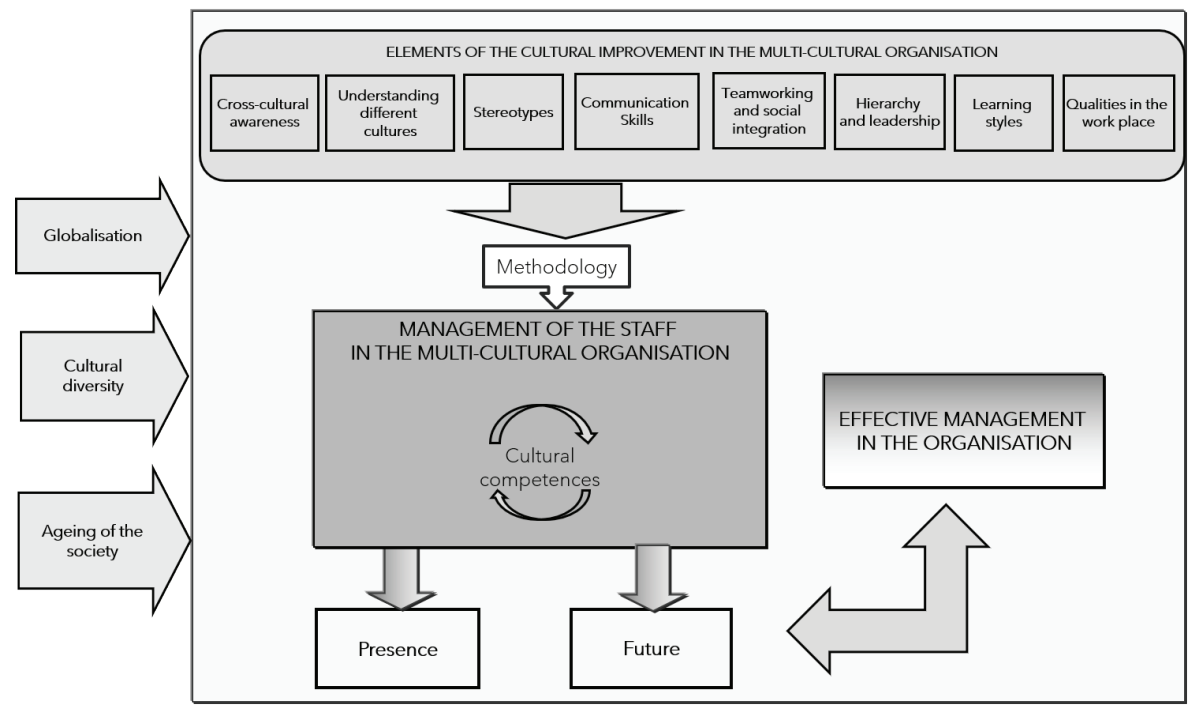

Fig. 1. General culture education-based model for organisation.

Source: own research.

The need for the development of the model comes from the different factors important in today's economy, i.e.: globalisation, internationalisation of organisations, cultural diversity, and the ageing of the society. All these factors directly influence the organisations, and this means that organisations must be ready for and react to changes. Globalisation means that the problems with traveling, mobilities, and cultural diversities almost disappear. People can work wherever they want, they can change their place of residence at any time and they meet people from different countries, very often so different from their own cultures. This causes that people must be culturally competent in order to function in such fast-paced world. On the other hand, the ageing of the society forces the countries to look abroad for workforce. This is linked with the necessity to get familiar with different cultures, different customs and practices; facing cultural diversity is inevitable. Therefore, these notions propelled the author to conduct the research on how multi-cultural organisations cope with such changes; they influence all the competences identified in Table 1 (see in Appendix) and therefore they are all included in the model in Figure 1. Taking the identified competences into account, which are all necessary for being competent in multicultural organisation, the organisation should design the path to improve them. It is crucial both for the present, but also for the future, because even if an organisation does not employ people from different cultures at this moment, it will be 
Journal of Education Culture and Society No. 2_2021

inevitable in the future. The earlier the process of understanding different cultures is implemented in the organisation, the more efficient the work and the more aware the employees can in the future.

In Figure 2, the author presents the path how to improve the cultural awareness of the staff in the multicultural organisation.

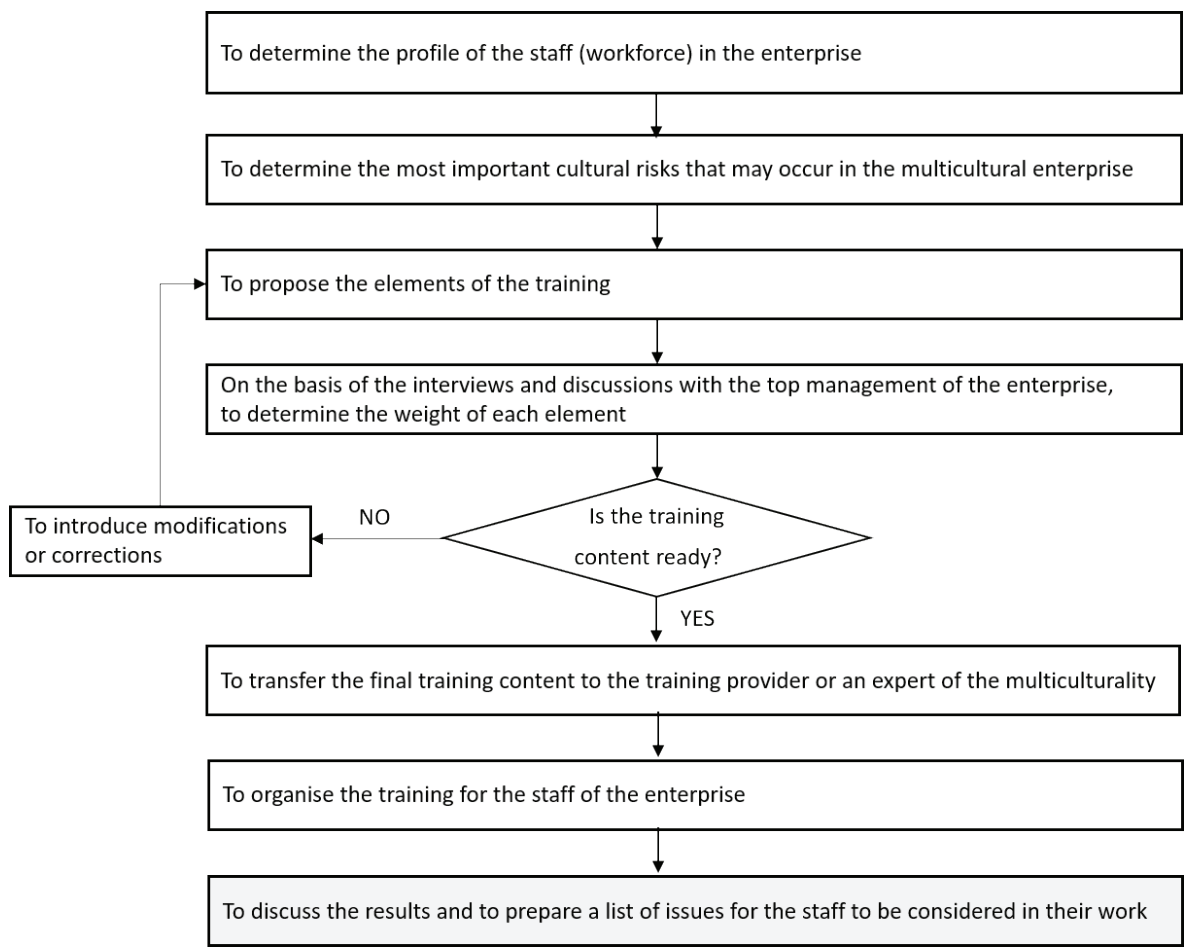

Fig. 2. The algorithm showing how to improve the cultural awareness of the staff in the multicultural organisation.

Source: own research.

The first step is to recognise the cultural background of the staff employed in the organisation. This approach should be taken if the employees come from different cultural backgrounds, as such origins may lead to conflicts and mutual misunderstanding. Then, the representatives of the managerial staff should identify which cultural risks may occur between the employees, and from where these risks stem. This information is crucial for the next step, which involves the selection of the elements of the training course. In this case, the main elements of the training course are decided upon by the managerial staff and not by the training course provider. This stems from the fact that they are most knowledgeable about the staff of the enterprise and the relations between them. Afterwards, the managerial staff discusses the main elements of the training course with the employees to be sure that they are the right ones. 
Additional elements may be added if needed. The managerial staff can also try to identify the weights for each element to advise the training course provider as to which of them are the most important for this individual enterprise and this individual training course. If the content of the training course is not ready, there is no possibility to move to the next steps. Once the elements of the training course are decided upon, they are transferred to the training course provider or an expert who is to run the training course. Therefore, the training course is in fact organised by a third party. The last step concerns the analysis of the results and providing feedback regarding the recommended focus that should be assumed when working in a multicultural environment.

The author assumes that training courses should be organised on a regular basis. It is not enough to train the staff irregularly. They should acquire, but also improve, their competences in the area of multiculturality in the enterprise and understanding different cultures.

\section{CONCLUSION}

The research has highlighted the need to consider the cultural diversity in multicultural organisations. Despite offering good working conditions, an organisation may still be prone to cultural risks. Therefore, the most important objective of intercultural education in the enterprise is to develop appropriate abilities which facilitate interaction and communication between employees from different cultures, i.e.: a wider understanding of cultures in modern societies; a better ability to communicate with people from different cultural backgrounds; more flexible relations to cultural diversity in the society; a greater ability to participate in social interactions and recognition of common heritage of humanity.

The proposed culture education-based model indicates which elements are most important when working with people from different cultures. It seems that if an organisation systematically trains employees in the culture-related areas, it can positively influence the effectiveness of work and minimise the rate of negative personal contacts.

The research has not indicated the reasons for negative cultural behaviour in the workplace. This can be the topic of further research as it is interesting to get to know why people behave in different ways towards employees from different cultural backgrounds.

\section{ACKNOWLEDGEMENTS}

The work is part-funded by the European Commission (Erasmus+ programme - No.2018-1-PL01-KA204-051056 "Cultural risk in the organisation in the globalisation era - competences vs. reality"). 


\section{REFERENCES}

[1] Adamczyk, M. (2017). The importance of cultural differences in international business. Central European Review of Economics and Management, 1(2), 151-170.

[2] Allievi, S. (2010). Immigration and cultural pluralism in Italy: multiculturalism as a missing model. Italian Culture, 28(2), 85-103.

[3] Brands-Kehre, I. (2010). Pilsonība, līdzdalība un pārstāvniecỉba [Citizenship, participation, and representation]. In: N. Muižnieks (Ed.), Cik integrēta ir Latvijas sabiedriba? Sasniegumu, neveiksmju un izaicinäjumu audits [How integrated is Latvian society? Audit of achievements, failures, and challenges] (pp. 95-124). Rīga: LU Akadēmiskais Apgāds.

[4] Brünnemann, K. (2013). The strategic importance of intercultural competency for project managers for the $21^{\text {st }}$ century. Working Papers Series by the University of Applied Sciences BFI Vienna, 79.

[5] Burke, H. (2019). Living and working in Europe 2015-2018. Luxembourg: Publications Office of the European Union.

[6] Bussotti, L. (2017). The Italian way to intercultural education: innovation and resistance. Foro de Educación, 15(23), 43-68.

[7] Czaińska, K. (2017). Wielokulturowe zasoby ludzkie jako podmiot strategii marketingowych małych i średnich przedsiębiorstw w Polsce [Multicultural human resources as an issue of marketing strategies in SMEs in Poland]. Zeszyty Naukowe Uniwersytetu Przyrodniczo-Humanistycznego w Siedlcach. Seria: Administracja i Zarzadzanie, 40(113), 61-70.

[8] Dębczyńska A. (2017). Cultural differences and Polish - Chinese business relations in practice. Journal of Corporate Responsibility and Leadership. The Challenges of Contemporary Management in the Global Economy, 4(2), 8-24.

[9] ERASMUS+ project. (2019). Cultural risk in the organisation in the globalisation era competences vs. reality (ERASMUS+) - Comparative report. Retrieved June 30, 2021 from http://culturalrisk.eu/ wp-content/uploads/2021/04/Comparative-report-on-competences_EN.pdf

[10] Hammer, M. R. (2009). The intercultural development inventory: an approach for assessing and building intercultural competence. In: M. A. Moodian (Ed.), Contemporary leadership and intercultural competence: exploring the cross-cultural dynamics within organisations (pp. 203-218). SAGE Publications, Inc.

[11] Hanovs, D. (2016). Can postcolonial theory help explain Latvian politics of integration? Reflections on contemporary Latvia as a postcolonial society. Journal of Baltic Studies, 47(1), 133-153.

[12] Heinz, K. (2014). Multicultural team conflict management. Securitologia, 19(1), 117-128.

[13] Hussain, S. (2018). Managing communication challenges in multicultural organisations. International Journal of Media, Journalism and Mass Communications, 4(2), 44-49 doi:10.20431/2454-9479.0402005

[14] Jackson, J. (2015). Becoming interculturally competent: theory to practice in international education. International Journal of Intercultural Relations, 48, 91-107.

[15] Jain, T., \& Pareek, C. (2019). Managing cross-cultural diversity: Issues and challenges. Global Management Review, 13(2), 23-32.

[16] Jones, K. P., Peddie, C. I., Gilrane, V. L., King, E. B., \& Gray, A. B. (2016). Not so subtle: a metaanalytic investigation of the correlates of subtle and overt discrimination. Journal of Management, 42(6), 1588-1613.

[17] Kostrzyńska, A. (2018). Wielokulturowość w biznesie i organisacji [Multiculturality in business and organisation]. Retrieved May 10, 2021 from https://eksport.pl/2018/02/23/ wielokulturowosc-biznesie-organisacji/

[18] McLaughlin, M. E., Bell, M. P., \& Stringer, D. Y. (2004). Stigma and acceptance of persons with disabilities: understudied aspects of workforce diversity. Group and Organisation Management, 29(3), 302-333.

[19] Quillian, L., Pager, D., Hexel, O., \& Midtboen. (2017). Meta-analysis of field experiments shows no change in racial discrimination in hiring over time. Proceedings of the National Academy of Sciences, 114(41), 10870-10875.

[20] Rožukalne, A., Kruks, S., Skulte, I., Lūse, A., \& Stakle, A. (2017). Migrācijas atspoguḷojums un rāmējums Latvijas medijos [Migration coverage and framing in Latvian media]. Retrieved May 1, 2021, from https://www.km.gov.lv/uploads/ckeditor/files/Sabiedribas_integracija/Petijumi/Migracijas\%20atspogulojums\%20un\%20ramejums\%20LV\%20medijos(2017).pdf

[21] Triana, M. D. C., Jaysinghe, M. \& Pieper, J. R. (2015). Perceived workplace racial discrimination and its correlates: a meta-analysis. Journal of Organisational Behaviour, 36(4), 491-513. 


\section{APPENDIX}

This appendix consists of the research analysis related to the competences which should be acquired by the staff of multicultural organisations in order to improve their effectiveness of work and better communication with people from different cultures. The questionnaire with the list of competences included in the table were transferred to 154 people from the multicultural organisations in Poland, Latvia, Italy, Cyprus, and the United Kingdom.

Table 1.

Competences needed for the staff of multicultural organisations $(N=154)$

\begin{tabular}{|c|c|c|c|c|c|c|}
\hline & Total & Cyprus & Italy & Latvia & Poland & UK \\
\hline $\begin{array}{l}\text { To understand why people from } \\
\text { different cultures can behave differently } \\
\text { (M2) }\end{array}$ & 3.67 & 3.71 & 3.64 & 3.62 & 3.70 & 3.67 \\
\hline $\begin{array}{l}\text { To identify effective ways to solve } \\
\text { problems in a multicultural organisation } \\
\text { (M5) }\end{array}$ & 3.53 & 3.79 & 3.45 & 3.50 & 3.47 & 3.37 \\
\hline $\begin{array}{l}\text { To understand the role of tolerance } \\
\text { between people from different cultures } \\
\text { (M2) }\end{array}$ & 3.52 & 3.53 & 3.63 & 3.59 & 3.31 & 3.52 \\
\hline $\begin{array}{l}\text { To analyse differences in meanings of } \\
\text { one word or sign in different languages } \\
\text { (M4) }\end{array}$ & 3.46 & 3.82 & 3.36 & 3.21 & 3.53 & 3.33 \\
\hline $\begin{array}{l}\text { To identify possible cultural biases, } \\
\text { prejudices and beliefs (M3) }\end{array}$ & 3.44 & 3.63 & 3.48 & 3.17 & 3.39 & 3.48 \\
\hline $\begin{array}{l}\text { To analyse how different learning styles } \\
\text { can influence the effectiveness of work } \\
\text { in a multicultural organisation (M7) }\end{array}$ & 3.39 & 3.65 & 3.21 & 3.36 & 3.08 & 3.62 \\
\hline $\begin{array}{l}\text { To recognise different communication } \\
\text { styles (M4) }\end{array}$ & 3.38 & 3.18 & 3.48 & 3.37 & 3.27 & 3.63 \\
\hline $\begin{array}{l}\text { To identify and to analyse other } \\
\text { different factors as e.g.: punctuality, } \\
\text { precision, and efficiency, which can } \\
\text { ensure good work (M8) }\end{array}$ & 3.38 & 3.85 & 3.21 & 3.21 & 3.43 & 3.12 \\
\hline $\begin{array}{l}\text { To analyse key cultural drivers and } \\
\text { attitudes (i.e.: time, space, authority, } \\
\text { risk, tasks and relationships) (M2) }\end{array}$ & 3.37 & 3.59 & 3.32 & 3.30 & 3.28 & 3.30 \\
\hline $\begin{array}{l}\text { To identify the main reasons for cultural } \\
\text { stereotypes (M4) }\end{array}$ & 3.34 & 3.62 & 3.34 & 3.03 & 3.34 & 3.31 \\
\hline $\begin{array}{l}\text { To analyse the main differences } \\
\text { between own and other cultures (M1) }\end{array}$ & 3.32 & 3.38 & 3.30 & 3.24 & 3.40 & 3.28 \\
\hline $\begin{array}{l}\text { To identify nuances in cultural norms } \\
\text { and values (M2) }\end{array}$ & 3.31 & 3.41 & 3.29 & 3.24 & 3.13 & 3.50 \\
\hline $\begin{array}{l}\text { To analyse the influence of cultural } \\
\text { stereotypes on people working in a } \\
\text { multicultural organisation and the } \\
\text { effectiveness of their work (M4) }\end{array}$ & 3.31 & 3.79 & 3.39 & 2.93 & 3.33 & 2.91 \\
\hline $\begin{array}{l}\text { To analyse how to divide } \\
\text { responsibilities in the organisation (M6) }\end{array}$ & 3.30 & 3.62 & 3.16 & 3.21 & 3.27 & 3.20 \\
\hline
\end{tabular}




\begin{tabular}{|c|c|c|c|c|c|c|}
\hline & Total & Cyprus & Italy & Latvia & Poland & UK \\
\hline $\begin{array}{l}\text { To analyse the relations between people } \\
\text { in a multicultural organisation (M6) }\end{array}$ & 3.30 & 3.47 & 3.30 & 3.29 & 3.15 & 3.27 \\
\hline $\begin{array}{l}\text { To identify own style of communication } \\
\text { (M4) }\end{array}$ & 3.29 & 3.21 & 3.35 & 3.23 & 3.30 & 3.37 \\
\hline $\begin{array}{l}\text { To identify changes that are needed } \\
\text { in multicultural teams (e.g. related to } \\
\text { the management, responsibilities of } \\
\text { employees, organisation of works) (M5) }\end{array}$ & 3.29 & 3.68 & 3.33 & 2.97 & 3.17 & 3.26 \\
\hline $\begin{array}{l}\text { To identify and analyse artefacts in } \\
\text { a multicultural organisation (e.g. } \\
\text { behaviours of the employees towards } \\
\text { new employees; meetings of employees } \\
\text { outside the company aimed at their } \\
\text { better integration; other ceremonies and } \\
\text { rituals in the organisation) (M6) }\end{array}$ & 3.27 & 3.50 & 3.24 & 3.30 & 2.97 & 3.32 \\
\hline $\begin{array}{l}\text { To distinguish between different social } \\
\text { and individual cultural norms (M1) }\end{array}$ & 3.26 & 3.82 & 3.28 & 2.93 & 2.90 & 3.27 \\
\hline $\begin{array}{l}\text { To analyse how to introduce changes in } \\
\text { the organisation (M6) }\end{array}$ & 3.26 & 3.35 & 3.52 & 3.03 & 2.93 & 3.42 \\
\hline $\begin{array}{l}\text { To identify and analyse basic norms and } \\
\text { values in the organisation (M6) }\end{array}$ & 3.25 & 3.50 & 3.15 & 3.20 & 2.97 & 3.42 \\
\hline $\begin{array}{l}\text { To define the concepts of "culture", } \\
\text { "cultural awareness", "culture } \\
\text { sensitivity" and "culture shock" (M1) }\end{array}$ & 3.17 & 3.50 & 3.33 & 3.10 & 2.79 & 3.00 \\
\hline To identify own learning style (M7) & 3.13 & 3.06 & 3.09 & 3.23 & 2.88 & 3.41 \\
\hline $\begin{array}{l}\text { To analyse the role of emotions in a } \\
\text { multicultural team (M5) }\end{array}$ & 3.11 & 3.48 & 3.21 & 2.90 & 2.83 & 3.08 \\
\hline $\begin{array}{l}\text { To identify different learning styles } \\
\text { (M7) }\end{array}$ & 3.11 & 3.21 & 3.19 & 3.07 & 2.62 & 3.44 \\
\hline $\begin{array}{l}\text { To define the term "assertiveness" } \\
\text { as an important characteristic at the } \\
\text { workplace (M8) }\end{array}$ & 3.08 & 3.44 & 2.97 & 3.21 & 2.86 & 2.83 \\
\hline $\begin{array}{l}\text { To analyse different cultures in the } \\
\text { organisation, i.e.: masculinity or } \\
\text { femininity culture (M6) }\end{array}$ & 3.07 & 2.61 & 3.33 & 3.07 & 3.24 & 3.16 \\
\hline $\begin{array}{l}\text { To identify the role of humour as an } \\
\text { important element that can support } \\
\text { effectiveness at the workplace (M8) }\end{array}$ & 3.07 & 3.24 & 2.94 & 3.21 & 2.87 & 3.13 \\
\hline $\begin{array}{l}\text { To define the term "cultural } \\
\text { stereotypes" (M4) }\end{array}$ & 3.05 & 3.15 & 3.06 & 3.00 & 2.97 & 3.04 \\
\hline $\begin{array}{l}\text { To recognise the most popular cultures } \\
\text { in Europe (M2) }\end{array}$ & 3.01 & 2.85 & 2.94 & 3.24 & 3.13 & 2.88 \\
\hline $\begin{array}{l}\text { To define the term "adaptation" as a } \\
\text { key element to work effectively in a } \\
\text { multicultural organisation (M5) }\end{array}$ & 2.96 & 3.32 & 3.06 & 3.00 & 2.41 & 2.90 \\
\hline $\begin{array}{l}\text { To define the term "intercultural } \\
\text { learning" (M7) }\end{array}$ & 2.95 & 3.32 & 3.03 & 3.03 & 2.65 & 2.54 \\
\hline $\begin{array}{l}\text { To perceive the role of direct } \\
\text { presentation of the work results to other } \\
\text { employees (e.g.: in the form of oral or } \\
\text { PPT presentations) as an important } \\
\text { technique in everyday work (M8) }\end{array}$ & 2.92 & 3.24 & 2.88 & 2.93 & 2.66 & 2.83 \\
\hline
\end{tabular}




\begin{tabular}{lcccccc}
\hline & Total & Cyprus & Italy & Latvia & Poland & UK \\
\hline $\begin{array}{l}\text { To get familiar with interesting } \\
\text { models of culture, i.e.: the Iceberg }\end{array}$ & & & & & & \\
$\begin{array}{l}\text { Model of Culture, Hofstede's Cultural } \\
\begin{array}{l}\text { Dimensions Theory, Milton Bennett's } \\
\text { Cultural Sensitivity Model (M1) }\end{array}\end{array}$ & $\mathbf{2 . 5 3}$ & 3.22 & $\mathbf{2 . 5 7}$ & $\mathbf{2 . 1 9}$ & $\mathbf{2 . 4 1}$ & $\mathbf{2 . 1 8}$ \\
\hline
\end{tabular}

Source: Cultural risk in the organisation in the globalisation era competences vs. reality (ERASMUS+) - Comparative report, 2019. Retrieved June 30, 2021 from http://culturalrisk.eu/wp-content/ uploads/2021/04/Comparative-report-on-competences_EN.pdf 